\title{
Analisis Perwilayahan Komoditas Kedelai di kabupaten Jember
}

\section{Regional Analysis Of Soybean Commodities in Jember Regency}

\author{
Linda Ekadewi Widyatami ${ }^{\# 1}$, Ardhitya Alam Wiguna ${ }^{\# 2}$ \\ ${ }^{\#}$ Manajemen Agribisnis Politeknik Negeri Jember \\ Jalan Mastrip Kotak Pos 164 Jember \\ ${ }^{1}$ linda_e.widyatami@yahoo.co.id \\ 2ardhitya.alamegmail.com
}

\begin{abstract}
In the province of East Java, Jember Regency is sixth largest soybean producer with total production are 25.178 tons in the 2015. Soybean Commodities in Jember Regency was an area harvested in 2015 covered an area of 12.238 Ha spread over several districts in Jember Regency. This research was intended to determine the soybean centers on Jember Regency, distribution characteristics of soybean comodities in the bases sector regional of Jember Regency, and the role of soybean comodities in supporting of agricultural sector in Jember Regency. The analysis methods used in this research were Location Quotient (LQ) analysis, lokalita analysis and specialization analysis of soybean commodities, as well as Analysis of Basic Service Ratio (BSR), Regional Multiplier (RM), and Short Multiplier. Results Location Quotient (LQ) Analysis showed that the base area of soybean comodities based on indicators of harvested area consists of 10 subdistricts they were: Bangsalsari Sub District, Umbulsari, Jombang, Balung, Rambipuji, Ajung, Kaliwates, Kencong, Jenggawah, and Ambulu Sub District. Soybean commodities base area based on indicators of production consists of 9 subdistricts they were: Bangsalsari Sub District, Umbulsari, Balung, Rambipuji, Jombang, Ajung, Kaliwates, Kencong, and Jenggawah Sub District. Commodities soybean farming in Jember Regency were not concentrated in one area, but spread across several districts in Jember Regency, and were not specialized in soybeans commodity farm. Commodities soybean farming in Jember Regency also could participate in support the agricultural sectors of food crops in Jember Regency.
\end{abstract}

Keywords : Regional Analysis, Location Quotient (LQ) Analysis, lokalita and specialization analysis,soybean commodities

\section{PENDAHULUAN}

Kedelai sebagai salah satu tanaman pangan di Indonesia yang banyak diolah menjadi berbagai produk, baik produk pangan, obat-obatan, industri maupun pakan. Produk olahan kedelai yang popular di masyarakat dewasa ini adalah produk fermentasi seperti tempe, kecap, tauco dan produk non fermentasi seperti tahu, susu, dan daging tiruan (meat analog). Komoditi tanaman kedelai di Jawa Timur mencapai 350 ribu ton dari 700-800 ribu ton produksi kedelai nasional per tahun. Hal ini berarti Jawa Timur merupakan sentra produksi kedelai dengan $42 \%$ produksi kedelai nasional berasal dari Jawa Timur. Daerahdaerah penyangga komoditi tanaman kedelai di Jawa Timur meliputi Kabupaten Banyuwangi dengan jumlah produksi adalah 44.636 Ton, kemudian Kabupaten Sampang dengan jumlah produksi adalah 41.689 Ton, Kabupaten Bojonegoro dengan jumlah produksi 28.056 Ton, Kabupaten Ponorogo 27.414 Ton, Lamongan 27.096 Ton, sedangkan Kabupaten Jember berada di posisi keenam dengan jumlah produksi adalah 25.178 ton pada Tahun 2015 .

Kabupaten Jember merupakan kabupaten dengan luas wilayah $3.293 \mathrm{~km}^{2}$, dengan luas yang sangat besar tersebut terdapat beberapa sub sektor komoditi yang ada di Kabupaten Jember, mulai dari sub sektor tanaman pangan, perkebunan dan kawasan kehutanan, untuk sub sektor tanaman pangan terdapat beberapa komoditi unggulan mulai dari tanaman padi, jagung dan kedelai. Komoditas kedelai memiliki luas area panen pada tahun 2015 seluas $12.238 \mathrm{Ha}$ yang tersebar di 
beberapa kecamatan di Kabupaten Jember, untuk mengetahui sentra komoditas kedelai di Kabupetan Jember ini, akan dilakukan penelitian tentang Analisis Perwilayahan Tanaman Kedelai di Kabupaten Jember.

\section{METODE PENELITIAN}

Daerah penelitian ditentukan berdasarkan metode yang disengaja (Purposive Methode) [9]. Data yang digunakan dalam penelitian adalah data sekunder, yaitu Data Produksi Kedelai dan Data Luas Areal Panen Kedelai Tahun 2010-2015 di Kabupaten Jember, serta data Harga Kedelai Tahun 2010-2015 di Kabupaten Jember.Data Sekunder diperoleh dari Badan Pusat Statistik (BPS) Kabupaten Jember, dan Dinas Pertanian Kabupaten Jember.

Metode Analisis yang digunakan untuk mengetahui wilayah basis dan non basis komoditas kedelai di Kabupetan Jember adalah metode analisis Location Quotient (LQ) dengan rumus sebagai berikut [16] :

$$
\mathrm{LQ}=\frac{(v i / v t)}{(V i / V t)}
$$

Keterangan :

$\mathrm{LQ}=$ Location Quotient komoditas strategis $\mathrm{di}$ suatu wilayah.

vi = Jumlah produksi/ luas areal panen di Kecamatan-i

$\mathrm{vt}=$ Jumlah produksi/ luas areal panen $\mathrm{di}$ Kabupaten-i

$\mathrm{Vi}=$ Total jumlah produksi/ luas areal panen sub sektor pertanian di Kecamatan-i

$\mathrm{Vt}=$ Total jumlah produksi/ luas areal panen sub sektor pertanian di Kabupaten-i

Kriteria pengambilan keputusan :

$\mathrm{LQ} \geq 1$ : Wilayah (i) merupakan wilayah basis produksi/ luas areal panen

LQ $<1$ : Wilayah (i) merupakan wilayah non basis produksi/ luas areal panen

Untuk mengetahui karakteristik penyebaran komoditas kedelai di Kabupaten Jember digunakan analisis lokalita dan spesialisasi[15].

a) Lokalita (Lp), digunakan untuk mengukur penyebaran (konsentrasi) relatif kegiatan pertanian di suatu wilayah dengan rumus :

$$
\begin{array}{ll}
\mathrm{Lp} & =\left\{(\mathrm{Si} / \mathrm{Ni})-\left(\sum \mathrm{Si} / \sum \mathrm{Ni}\right)\right\} \\
\alpha & =\mathrm{Lp}(+)
\end{array}
$$

Kriteria pengambilan keputusan :

$\alpha \geq 1$ : Komoditas-i terkonsentrasi pada suatu Kecamatan-i

$\alpha<1$ : Komoditas-i tersebar di beberapa wilayah di Kecamatan-i

b) Spesialisasi (Sp), digunakan untuk melihat spesialisasi wilayah terhadap jenis pertanian tertentu, dengan rumus:

$$
\begin{array}{ll}
\mathrm{Sp} & =\left\{\left(\mathrm{Si} / \sum \mathrm{Si}\right)-\left(\mathrm{Ni} / \sum \mathrm{Ni}\right)\right\} \\
\beta & =\mathrm{Sp}(+)
\end{array}
$$

Kriteria pengambilan keputusan :

$\beta \geq 1$ : Suatu wilayah menspesialisasikan pada satu jenis komoditas-i

$\beta<1$ : Suatu wilayah tidak menspesialisasikan pada satu jenis komoditas-i

Keterangan rumus Lp dan Sp :

$\mathrm{Si}=$ Jumlah produksi/ luas panen komoditas-i di Kecamatan-i

$\mathrm{Ni}=$ Jumlah produksi/ luas panen komoditas- $\mathrm{i}$ di Kabupaten-i

$\sum \mathrm{Si}=$ Total produksi/ luas panen sub sektor pertanian komoditas-i di Kecamatan-i

$\sum \mathrm{Ni}=$ Total produksi $/$ luas panen sub sektor pertanian komoditas-i di Kabupaten-i

Untuk mengetahui peranan komoditas strategis sebagai sektor basis dalam mendukung perkembangan kegiatan sektor pertanian terutama mensejahterakan masyarakat dalam menciptakan lapangan pekerjaan dan memperbaiki pendapatan di Kabupaten Jember digunakan analisis Basic Service Ratio (BSR), Regional Multiplier (RM), dan Short Multiplier[15], dengan rumus sebagai berikut:

$$
\begin{gathered}
\text { BSR }=\frac{\sum \text { Sektor basis }}{\sum \text { Sektor non basis }} \\
\mathrm{RM}=\frac{\sum \text { Sektor basis }+\sum \text { Sektor non basis }}{\sum \text { Sektor basis }}
\end{gathered}
$$

Pengganda Jangka Pendek (Short Multiplier/SM):

$$
\mathrm{SM}=\frac{\boldsymbol{Y B}+\boldsymbol{Y N}}{\boldsymbol{Y B}}
$$

Keterangan :

$\mathrm{SM}=$ Pengganda jangka pendek

$\mathrm{YB}=$ Penerimaan basis

$\mathrm{YN}=$ Penerimaan non basis

Kriteria pengambilan keputusan :

BSR, RM, MS > 1 : Sektor basis mensejahterakan masyarakat sektor pertanian di Kabupaten Jember terutama menciptakan lapangan pekerjaan dan memperbaiki pendapatan.

BSR, RM, MS $\leq 1$ : Sektor basis tidak mensejahterakan masyarakat sektor pertanian di Kabupaten Jember.

Asumsi yang digunakan adalah:

1) Pola permintaan penduduk bersifat homogen artinya setiap penduduk di wilayah penelitian dianggap mempunyai pola permintaan yang sama dengan pola permintaan nasional.

2) Respon hubungan sektor basis terhadap permintaan luar wilayah dan respon dari sektor non basis terhadap perubahan sektor basis (time lag) diabaikan.

Penerimaan menggunakan harga rata-rata tahunan atas dasar harga yang berlaku dan 
Linda Ekadewi Widyatami, Ardhitya Alam Wiguna. Analisis Perwilayahan Komoditas Kedelai

Di kabupaten jember

mengabaikan perbedaan harga menurut jenis dan kualitas dalam satu komoditas.

\section{HASIL DAN PEMBAHASAN}

5.1Sektor Basis Komoditas Kedelai di Kabupaten Jember

Hasil analisis Location Quotient (LQ) wilayah basis komoditas kedelai di Kabupaten Jember berdasarkan indikator luas panen tahun 2010 - 2015, ditunjukkan pada Tabel 1.

Tabel 1. Nilai Location Quotient (LQ) Wilayah Basis Komoditas Kedelai Berdasarkan Indikator Luas Panen di Kabupaten Jember Tahun 2010 - 2015

\begin{tabular}{|c|c|c|c|c|c|c|c|c|}
\hline \multirow{2}{*}{$\begin{array}{l}\mathbf{N} \\
\mathbf{0}\end{array}$} & \multirow{2}{*}{ Kecamatan } & \multicolumn{5}{|c|}{ LQ Kedelai } & \multirow[b]{2}{*}{2015} & \multirow{2}{*}{$\begin{array}{l}\text { Rata- } \\
\text { rata }\end{array}$} \\
\hline & & 2010 & 2011 & 2012 & 2013 & 2014 & & \\
\hline 1 & Bangsalsari & 3,861 & 3,593 & 3,572 & 5,470 & 5,227 & 4,576 & 4,383 \\
\hline 2 & Umbulsari & 2,387 & 2,688 & 3,782 & 4,080 & 3,997 & 2,773 & 3,285 \\
\hline 3 & Balung & 2,585 & 2,084 & 2,363 & 2,987 & 1,610 & 1,733 & 2,227 \\
\hline 4 & Rambipuji & 2,315 & 2,398 & 3,161 & 1,670 & 0,464 & 0,962 & 1,829 \\
\hline 5 & Jombang & 1,109 & 1,538 & 1,468 & 2,143 & 2,285 & 2,091 & 1,772 \\
\hline 6 & Ajung & 1,251 & 1,242 & 1,458 & 2,118 & 1,783 & 1,698 & 1,591 \\
\hline 7 & Kaliwates & 1,366 & 0,369 & 1,649 & 2,155 & 1,983 & 1,884 & 1,568 \\
\hline 8 & Jenggawah & 1,073 & 1,359 & 1,336 & 1,723 & 1,701 & 1,489 & 1,447 \\
\hline 9 & Kencong & 1,031 & 1,521 & 1,323 & 1,168 & 1,324 & 2,035 & 1,400 \\
\hline 10 & Ambulu & 1,452 & 1,140 & 0,693 & 0,926 & 1,039 & 1,037 & 1,048 \\
\hline
\end{tabular}

Sumber: Data Diolah, 2016

Hasil analisis Location Quotient (LQ)

wilayah basis komoditas kedelai di Kabupaten Jember berdasarkan indikator luas panen tahun 2010 - 2015menunjukkan bahwa selama periode waktu tahun 2010 sampai dengan 2015 dari 31 Kecamatan di Kabupaten Jember terdapat 10 kecamatan yang memiliki nilai Analisis LQ lebih besar (> 1), yang berarti bahwa 10 kecamatan tersebut merupakan wilayah basis luas panen komoditas kedelai di Kabupaten Jember. Berdasarkan urutan nilai analisis LQ tertinggi kecamatan-kecamatan tersebut antara lain adalah Kecamatan Bangsalsari dengan nilai LQ 4,383, Umbulsari dengan nilai LQ 3,285, Balung dengan nilai LQ 2,227, Rambipuji dengan nilai LQ 1,829, Jombang dengan nilai LQ 1,772, Ajung dengan nilai LQ 1,591, Kaliwates dengan nilai LQ 1,568, Jenggawah dengan nilai LQ 1,447, Kencong dengan nilai LQ 1,400, serta Ambulu dengan nilai LQ 1,048, dengan demikian dapat dinyatakan bahwa 10 kecamatan tersebut memiliki luas panen kedelai yang mampu untuk mencukupi kebutuhan wilayahnya secara mandiri dan mampu menyokong kebutuhan komoditas kedelai wilayah lain.

Hasil analisis Location Quetient (LQ) komoditas kedelai berdasarkan indikator produksi di Kabupaten Jember periode Tahun 2010-1015 ditunjukkan pada Tabel 2.
Tabel 2.Nilai Location Quotient (LQ) Wilayah Basis Komoditas Kedelai Berdasarkan Indikator Produksi di Kabupaten Jember Tahun 2010 2015

\begin{tabular}{|c|c|c|c|c|c|c|c|}
\hline \multirow{2}{*}{ No Kecamatan } & \multicolumn{5}{|c|}{ LQ Kedelai } & & \multirow{2}{*}{$\begin{array}{c}\text { Rata- } \\
- \text { rata }\end{array}$} \\
\hline & 2010 & 2011 & 2012 & 2013 & 2014 & 2015 & \\
\hline
\end{tabular}

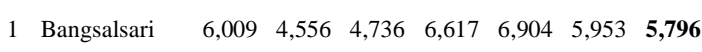

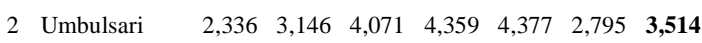

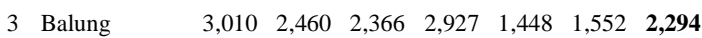

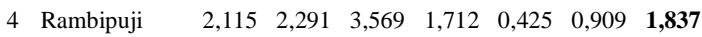

5 Jombang $\quad 0,994 \quad 1,474 \quad 1,406 \quad 2,081 \quad 2,384 \quad 2,211 \quad \mathbf{1 , 7 5 8}$

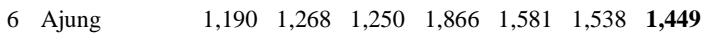

7 Kaliwates $\quad 1,209 \quad 0,338 \quad 1,460 \quad 2,178 \quad 1,691 \quad 1,675 \quad \mathbf{1 , 4 2 5}$

8 Kencong $\quad 0,961 \quad 1,773 \quad 1,175 \quad 1,049 \quad 1,181 \quad 1,946 \quad \mathbf{1 , 3 4 8}$

\begin{tabular}{lllllllll}
9 & Jenggawah & 0,894 & 1,353 & 1,158 & 1,498 & 1,563 & 1,388 & $\mathbf{1 , 3 0 9}$ \\
\hline
\end{tabular} Sumber: Data Diolah, 2016

Hasil analisis LQ wilayah basis komoditas kedelai berdasarkan indikator produksi di Kabupaten Jember periode 2010-2015 menunjukkan bahwa dari 31 Kecamatan di Kabupaten Jember terdapat 9 Kecamatan di Kabupaten Jember yang memiliki nilai LQ produksi komoditas kedelai pada periode 20102015 lebih besar dari satu (> 1). Berdasarkan urutan nilai LQ tertinggi, kecamatan-kecamatan tersebut antara lain adalah Kecamatan Bangsalsari (Nilai LQ = 5,796), Kecamatan Umbulsari (Nilai LQ $=3,514$ ), Kecamatan Balung (Nilai LQ = 2,294), Kecamatan Rambipuji (Nilai LQ = 1,837), Kecamatan Jombang (Nilai LQ $=1,758$ ), Kecamatan Ajung (Nilai LQ = 1,449), Kecamatan Kaliwates (Nilai LQ $=1,425$ ), Kecamatan Kencong (Nilai LQ $=1,348$ ), dan Kecamatan Jenggawah (Nilai LQ $=1,309$ ). Hal ini menunjukkan bahwa kesembilan kecamatan tersebut merupakan wilayah basis komoditas kedelai berdasarkan indikator produksi di Kabupaten Jember selama periode 2010-2015, yang berarti kecamatan-kecamatan tersebut mampu memenuhi kebutuhan produksi komoditas kedelai di wilayahnya secara mandiri serta mampu memenuhi kebutuhan kedelai wilayah lain dalam kurun waktu 2010 sampai dengan 2015.

Wilayah basis komoditas kedelai berdasarkan indikator produksi di Kabupaten Jember yang tertinggi adalah Kecamatan Bangsalsari dengan nilai LQ sebesar 5,796, yang berarti bahwa 1 bagian produksi kedelai akan digunakan untuk memenuhi kebutuhan Kecamatan Bangsalsari dan sisanya sebesar 4,796 bagian untuk memenuhi kebutuhan komoditas kedelai di wilayah lain.

\subsection{Karakteristik Penyebaran Komoditas Kedelai di Kabupaten Jember}




\subsubsection{Lokalita Komoditas Kedelai di Kabupaten Jember}

Nilai koefisien lokalita komoditas kedelai di Kabupaten Jember Tahun 2010-2015 berdasarkan indikator luas panen ditunjukkan pada Tabel 3.

Tabel 3. Nilai Koefisien Lokalita $(\alpha+)$ Komoditas

Kedelai Berdasarkan Indikator Luas

Panen di Kabupaten Jember Tahun 2010 -

2015

\begin{tabular}{|c|c|c|c|c|c|c|c|c|}
\hline \multirow{2}{*}{$\begin{array}{c}\mathbf{N} \\
\mathbf{0}\end{array}$} & \multirow{2}{*}{ Kecamatan } & \multicolumn{6}{|c|}{ Nilai Koefisien Lokalita $(\alpha)$} & \multirow{2}{*}{$\begin{array}{l}\text { Rata } \\
\text {-rata }\end{array}$} \\
\hline & & 2010 & 2011 & 2012 & 2013 & 2014 & 2015 & \\
\hline 1 & Bangsalsari & $\begin{array}{c}0,16 \\
1\end{array}$ & 0,146 & 0,144 & 0,258 & 0,244 & 0,199 & 0,192 \\
\hline 2 & Umbulsari & $\begin{array}{c}0,04 \\
9\end{array}$ & 0,058 & 0,087 & 0,069 & 0,062 & 0,032 & 0,060 \\
\hline & Balung & $\begin{array}{c}0,06 \\
4 \\
0,04\end{array}$ & 0,041 & 0,054 & 0,076 & 0,021 & 0,027 & 0,047 \\
\hline & Rambipuji & & 0,047 & 0,082 & 0,026 & $-0,023$ & $-0,002$ & 0,029 \\
\hline 5 & Jombang & $\begin{array}{c}4 \\
0,00\end{array}$ & 0,017 & 0,016 & 0,044 & 0,044 & 0,039 & 0,027 \\
\hline & Ajung & $\begin{array}{c}9 \\
0,00\end{array}$ & 0,008 & 0,016 & 0,041 & 0,028 & 0,025 & 0,021 \\
\hline & Jenggawah & $\begin{array}{c}3 \\
0,00\end{array}$ & 0,016 & 0,015 & 0,032 & 0,030 & 0,021 & 0,019 \\
\hline 8 & Kencong & $\begin{array}{c}1 \\
0,00\end{array}$ & 0,019 & 0,012 & 0,006 & 0,010 & 0,043 & 0,015 \\
\hline 9 & Kaliwates & $\begin{array}{c}3 \\
0,01\end{array}$ & $-0,006$ & 0,005 & 0,009 & 0,008 & 0,007 & 0,004 \\
\hline 10 & Ambulu & 8 & 0,005 & $-0,010$ & $-0,002$ & 0,002 & 0,001 & 0,002 \\
\hline & Rata-rata & $\begin{array}{c}0,03 \\
6\end{array}$ & 0,035 & 0,042 & 0,056 & 0,043 & 0,039 & 0,042 \\
\hline
\end{tabular}

indikator luas panen menunjukkan bahwa dari 31 Kecamatan di Kabupaten Jember terdapat sepuluh (10) kecamatan di Kabupaten Jember yang mempunyai nilai lokalita positif $(\alpha+)$, yaitu Kecamatan Bangsalsari dengan nilai lokalitas positif $(0,192)$, Umbulsari $(\alpha=0,060)$, Balung $(\alpha=$ 0047), Rambipuji $(\alpha=0,029)$, Jombang $(\alpha=$ $0,027)$, Ajung $(\alpha=0,021)$, Jenggawah $(\alpha=0,019)$, Kencong $(\alpha=0,015)$, Kaliwates $(\alpha=0,004)$, dan Kecamatan Ambulu $(\alpha=0,002)$. Nilai rata-rata lokalita komoditas kedelai pada sepuluh kecamatan basis di Kabupaten Jember periode tahun 2010-2015 menunjukkan nilai positif kurang dari satu $(<1)$, dan untuk nilai rata-rata total analisis lokalita luas panen kedelai di Kabupaten Jember menunjukkan nilai kurang dari satu yaitu 0,042, yang berarti bahwa berdasarkan indikator luas panen komoditas kedelai tidak terkonsentrasi pada suatu kecamatan di Kabupaten Jember atau komoditas kedelai tersebar di beberapa wilayah kecamatan di Kabupaten Jember. Penyebaran usahatani komoditas kedelai yang tidak terkonsentrasi ini memberikan keuntungan bagi Kabupaten Jember karena penyedia luas areal panen kedelai untuk kebutuhan industri dan masyarakat di Kabupaten Jember tidak tergantung pada satu wilayah kecamatan saja, tetapi tersedia di beberapa kecamatan di Kabupaten Jember. Dalam hal ini wilayah basis komoditas kedelai masih memegang peranan penting sebagai wilayah yang mampu memenuhi kebutuhan wilayah lain.
Perkembangan koefisien lokalita dari komoditas kedelai berdasarkan indikator luas panen di Kabupaten Jember Tahun 2010-2015 disajikan pada gambar berikut ini:

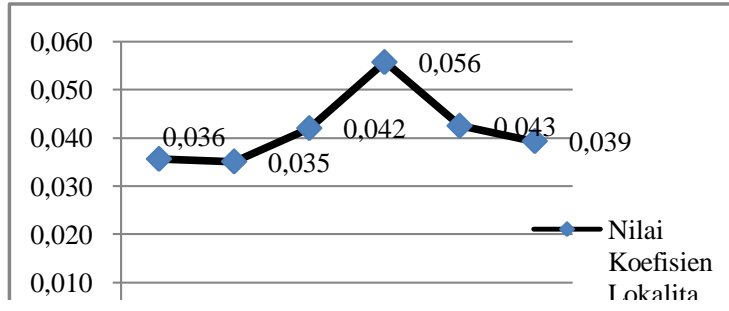

Gambar 1. Perkembangan Nilai Koefisiensi Lokalita $(\alpha)$ Komoditas Kedelai Berdasarkan Indikator Luas Panen di Kabupaten Jember Tahun 2010-2015

1na1kator produks1 d1 Kabupaten Jember periode tahun 2010-2015 (ditunjukkan pada Tabel 4), menunjukkan bahwa dari 31 Kecamatan di Kabupaten Jember terdapat sembilan (9) kecamatan yang memiliki nilai lokalita positif $(\alpha+)$, yaitu Kecamatan Bangsalsari dengan nilai lokalita $0,233$, Umbulsari $(\alpha=0,063)$, Balung ( $\alpha=0,050)$, Jombang ( $\alpha=0,027)$, Rambipuji $(\alpha=0,026)$, Ajung $(\alpha=0,016)$, Kencong $(\alpha=0,014)$, Jenggawah $(\alpha=0,013)$, dan Kecamatan Kaliwates $(\alpha=0,003)$. Nilai rata-rata lokalita produksi komoditas kedelai di masing-masing kesembilan kecamatan tersebut menunjukkan nilai positif yang kurang dari satu $(\alpha+<1)$, dan untuk nilai rata-rata total lokalita produksi komoditas kedelai di Kabupaten Jember selama periode 2010-2015 menunjukkan nilai positif yang kurang dari satu yaitu sebesar 0,049 , yang berarti bahwa komoditas kedelai tidak terkonsentrasi pada suatu kecamatan di Kabupaten Jember atau komoditas kedelai tersebar di beberapa wilayah kecamatan di Kabupaten Jember. Penyebaran usahatani komoditas kedelai yang tidak terkonsentrasi ini memberikan keuntungan bagi Kabupaten Jember karena penyedia produksi kedelai untuk kebutuhan industri dan masyarakat di Kabupaten Jember tidak tergantung pada satu wilayah kecamatan saja, tetapi tersedia di beberapa kecamatan di Kabupaten Jember. Dalam hal ini wilayah basis komoditas kedelai masih memegang peranan penting sebagai wilayah yang mampu memenuhi kebutuhan wilayah lain.

Tabel 4. Nilai Koefisien Lokalita $(\alpha+)$ Komoditas Kedelai Berdasarkan Indikator Produksi di Kabupaten Jember Tahun 2010 - 2015

\begin{tabular}{|c|c|c|c|c|c|c|c|c|}
\hline \multirow{2}{*}{$\mathbf{N}$} & \multirow{2}{*}{$\begin{array}{c}\text { Kecama } \\
\tan \end{array}$} & \multicolumn{5}{|c|}{ Nilai Koefisien Lokalita $(\alpha)$} & \multirow[b]{2}{*}{2015} & \multirow{2}{*}{$\begin{array}{l}\text { Rata } \\
\text {-rata }\end{array}$} \\
\hline & & 2010 & 2011 & $\begin{array}{c}201 \\
2\end{array}$ & $\begin{array}{c}201 \\
3\end{array}$ & 2014 & & \\
\hline 1 & Bangsals & 0,230 & 0,165 & 0,17 & 0,28 & 0,29 & 0,241 & 0,233 \\
\hline & Umbulsa & & & $0,0 \overline{9}$ & $0,0 \hat{7}$ & $0,0 \overline{6}$ & & \\
\hline 2 & ri & 0,044 & 0,062 & 7 & 6 & 8 & 0,034 & 0,063 \\
\hline 3 & Balung & 0,080 & 0,054 & $\begin{array}{r}0,05 \\
5\end{array}$ & $\begin{array}{r}0,07 \\
5\end{array}$ & $\begin{array}{r}0,01 \\
6\end{array}$ & 0,021 & 0,050 \\
\hline 4 & Jombang & 0,000 & 0,015 & $\begin{array}{r}0,01 \\
4\end{array}$ & $\begin{array}{r}0,04 \\
1\end{array}$ & $\begin{array}{r}0,04 \\
7\end{array}$ & 0,043 & $\mathbf{0 , 0 2 7}$ \\
\hline & Rambipu & & & 0,08 & 0,02 & 0,02 & - & \\
\hline 5 & $\mathrm{ji}$ & 0,035 & 0,039 & 4 & 7 & 5 & 0,004 & 0,026 \\
\hline
\end{tabular}


Linda Ekadewi Widyatami, Ardhitya Alam Wiguna. Analisis Perwilayahan Komoditas Kedelai Di kabupaten jember

\begin{tabular}{|c|c|c|c|c|c|c|c|c|}
\hline \multirow{3}{*}{6} & \multirow{3}{*}{ Ajung } & & \multirow{3}{*}{0,009} & 0,00 & 0,03 & 0,02 & & \multirow{3}{*}{0,016} \\
\hline & & 0,006 & & 9 & 2 & 1 & 0,019 & \\
\hline & & - & & 0,00 & 0,00 & 0,00 & & \\
\hline \multirow[t]{2}{*}{7} & Kencong & 0,001 & \multirow[t]{2}{*}{0,027} & 7 & 2 & 6 & \multirow{2}{*}{0,042} & \multirow[t]{2}{*}{0,014} \\
\hline & Jenggaw & - & & 0,00 & 0,02 & 0,02 & & \\
\hline \multirow[t]{2}{*}{8} & & 0,004 & 0,015 & 7 & 2 & 4 & \multirow{2}{*}{0,017} & \multirow[t]{2}{*}{0,013} \\
\hline & Kaliwate & & - & 0,00 & 0,00 & 0,00 & & \\
\hline \multirow[t]{2}{*}{9} & $\mathrm{~s}$ & 0,002 & 0,006 & 4 & 9 & 5 & 0,005 & 0,003 \\
\hline & $\begin{array}{l}\text { Rata- } \\
\text { rata }\end{array}$ & 0,044 & 0,042 & $\begin{array}{r}0,05 \\
0\end{array}$ & $\begin{array}{r}0,06 \\
3\end{array}$ & $\begin{array}{r}0,05 \\
1\end{array}$ & 0,046 & 0,049 \\
\hline
\end{tabular}

Perkembangan Koefisiensi Lokalita $(\alpha)$ dari komoditas kedelai berdasarkan indikator produksi di Kabupaten Jember Tahun 2010-2015 adalah sebagai berikut:

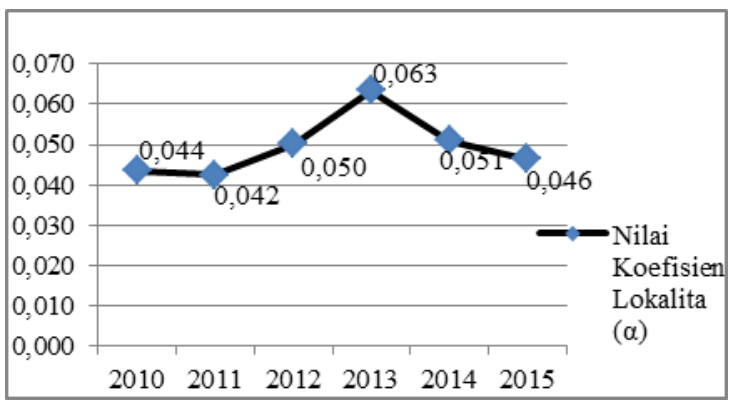

Gambar 2. Perkembangan Nilai Koefisiensi Lokalita $(\alpha)$ Komoditas Kedelai Berdasarkan Indikator Produksi di Kabupaten Jember Tahun 2010-2015

pada Tabel 5 .

Tabel 5. Nilai Koefisien Spesialisasi $(\beta+)$ Komoditas Kedelai di Kabupaten Jember Berdasarkan Indikator Luas Panen Tahun 2010 - 2015

\begin{tabular}{|c|c|c|c|c|c|c|c|c|}
\hline \multirow{2}{*}{$\begin{array}{l}\mathrm{N} \\
\mathrm{o}\end{array}$} & \multirow{2}{*}{ Kecamatan } & \multicolumn{6}{|c|}{ Nilai Koefisien Spesialisasi $(\beta)$} & \multirow{2}{*}{$\begin{array}{l}\text { Rata- } \\
\text { rata }\end{array}$} \\
\hline & & 2010 & 2011 & 2012 & 2013 & 2014 & 2015 & \\
\hline 1 & Bangsalsari & 0,161 & 0,289 & 0,155 & 0,180 & 0,205 & 0,176 & 0,194 \\
\hline 2 & Umbulsari & 0,078 & 0,097 & 0,168 & 0,124 & 0,145 & 0,087 & 0,116 \\
\hline 3 & Balung & 0,089 & 0,074 & 0,082 & 0,080 & 0,030 & 0,036 & 0,065 \\
\hline 4 & Rambipuji & 0,074 & 0,075 & 0,130 & 0,027 & $-0,026$ & $-0,002$ & 0,046 \\
\hline 5 & Jombang & 0,006 & 0,021 & 0,028 & 0,046 & 0,062 & 0,054 & 0,036 \\
\hline 6 & Ajung & 0,014 & 0,011 & 0,028 & 0,045 & 0,038 & 0,034 & 0,028 \\
\hline 7 & Jenggawah & 0,004 & 0,040 & 0,020 & 0,029 & 0,034 & 0,024 & 0,025 \\
\hline 8 & Kaliwates & 0,021 & $-0,059$ & 0,039 & 0,047 & 0,048 & 0,043 & 0,023 \\
\hline 9 & Kencong & 0,002 & 0,033 & 0,019 & 0,007 & 0,016 & 0,051 & 0,021 \\
\hline \multirow[t]{2}{*}{10} & Ambulu & 0,025 & 0,004 & $-0,019$ & $-0,003$ & 0,002 & 0,002 & 0,002 \\
\hline & Rata-rata & 0,047 & 0,059 & 0,065 & 0,058 & 0,055 & 0,050 & 0,056 \\
\hline
\end{tabular}

Sumber: Data Diolah, 2016

Hasil analisis spesialisasi berdasarkan indikator luas panen menunjukkan bahwa terdapat sepuluh (10) Kecamatan di Kabupaten Jember yang mempunyai nilai Spesialisasi positif $(\beta+)$, yaitu Kecamatan Bangsalsari sebesar 0,194; Umbulsari sebesar 0,016; Balung sebesar 0,065; Rambipuji sebesar 0,046; Jombang sebesar 0,036; Ajung sebesar 0,028, Jenggawah sebesar 0,025; Kaliwates sebesar 0,023; Kencong sebesar 0,021; serta Kecamatan Ambulu sebesar 0,002. Nilai ratarata spesialisasi komoditas kedelai berdasarkan indikator luas panen pada masing-masing kecamatan di Kabupaten Jember menunjukkan nilai positif yang kurang dari satu $(<1)$, nilai tersebut berarti bahwa kecamatan-kecamatan di Kabupaten Jember tersebut tidak menspesialisasikan pada usahatani komoditas kedelai. Nilai rata-rata total spesialisasi komoditas kedelai berdasarkan indikator luas panen di Kabupaten Jember selama periode 2010-2015 menunjukkan nilai positif kurang dari satu $(<1)$ yaitu sebesar 0,056, Nilai tersebut berarti bahwa Kabupaten Jember tidak menspesialisasikan pada usahatani komoditas kedelai.

Perkembangan Koefisiensi Spesialisasi $(\beta)$ dari komoditas kedelai berdasarkan indikator luas panen di Kabupaten Jember Tahun 2010-2015 adalah sebagai berikut:

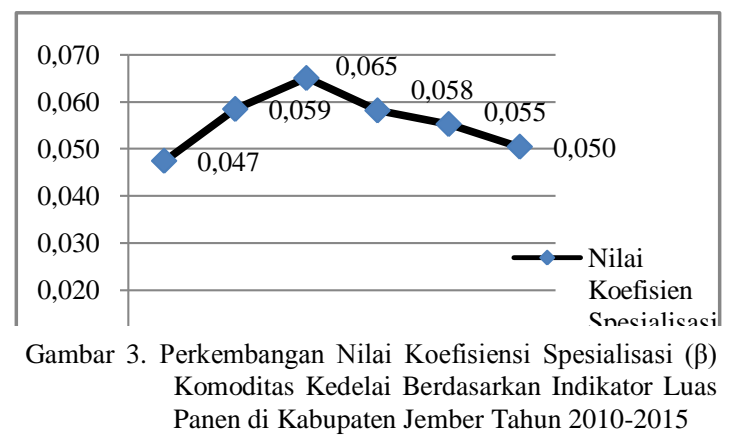

Kabupaten Jember berdasarkan indikator produksi pada periode tahun 2010-2015, ditunjukkan pada Tabel 6.

Tabel 6. Nilai Koefisien Spesialisasi ( $\beta$ ) Komoditas Kedelai Berdasarkan Indikator Produksi di Kabupaten Jember Tahun 2010 - 2015

\begin{tabular}{|c|c|c|c|c|c|c|c|c|}
\hline \multirow{2}{*}{$\begin{array}{l}\mathbf{N} \\
\mathbf{0}\end{array}$} & \multirow{2}{*}{ Kecamatan } & \multicolumn{6}{|c|}{ Nilai Koefisien Spesialisasi ( $\beta$ ) } & \multirow{2}{*}{$\begin{array}{l}\text { Rata- } \\
\text { rata }\end{array}$} \\
\hline & & 2010 & 2011 & 2012 & 2013 & 2014 & 2015 & \\
\hline 1 & Bangsalsari & 0,071 & 0,073 & 0,071 & 0,086 & 0,096 & 0,083 & 0,080 \\
\hline 2 & Umbulsari & 0,019 & 0,044 & 0,058 & 0,051 & 0,055 & 0,030 & 0,043 \\
\hline 3 & Balung & 0,028 & 0,030 & 0,026 & 0,030 & 0,007 & 0,009 & 0,022 \\
\hline 4 & Rambipuji & 0,016 & 0,026 & 0,049 & 0,011 & $-0,009$ & $-0,002$ & 0,015 \\
\hline 5 & Jombang & 0,000 & 0,010 & 0,008 & 0,017 & 0,022 & 0,020 & 0,013 \\
\hline 6 & Ajung & 0,003 & 0,005 & 0,005 & 0,013 & 0,009 & 0,009 & 0,007 \\
\hline 7 & Kaliwates & 0,003 & $-0,014$ & 0,009 & 0,018 & 0,011 & 0,011 & 0,006 \\
\hline 8 & Kencong & $-0,001$ & 0,016 & 0,003 & 0,001 & 0,003 & 0,016 & 0,006 \\
\hline 9 & Jenggawah & $-0,001$ & 0,007 & 0,003 & 0,008 & 0,009 & 0,006 & 0,005 \\
\hline & ata-rata & 0,015 & 0,022 & 0,026 & 0,026 & 0,023 & 0,020 & 0,022 \\
\hline
\end{tabular}

Sumber: Data Diolah, 2016

Hasil analisis spesialisasi kedelai di Kabupaten Jember berdasarkan indikator produksi pada periode tahun 2010-2015, menunjukkan bahwa terdapat sembilan (9) kecamatan di Kabupaten Jember yang memiliki nilai koefisien spesialisasi positif yaitu Kecamatan Bangsalsari sebesar 0,080; Umbulsari sebesar 0,043; Balung 
sebesar 0,022; Rambipuji sebesar 0,015; Jombang sebesar 0,013; Ajung sebesar 0,007; Kaliwates sebesar 0,006; Kencong sebesar 0,006; dan Kecamatan Jenggawah sebesar 0,005. Nilai ratarata spesialisasi komoditas kedelai berdasarkan indikator produksi pada masing-masing kecamatan di Kabupaten Jember tersebut menunjukkan nilai positif yang kurang dari satu $(<1)$, nilai ini berarti bahwa kecamatan-kecamatan tersebut tidak menspesialisasikan pada produksi usahatani komoditas kedelai. Nilai rata-rata total spesialisasi komoditas erdasakedelai brkan indikator produksi di Kabupaten Jember selama periode 2010-2015 menunjukkan nilai positif kurang dari satu $(<1)$ yaitu sebesar 0,022 . Nilai tersebut berarti bahwa Kabupaten Jember tidak menspesialisasikan pada usahatani komoditas kedelai.

Perkembangan Koefisiensi Spesialisasi ( $\beta$ ) dari komoditas kedelai berdasarkan indikator produksi di Kabupaten Jember Tahun 2010-2015 adalah sebagai berikut:

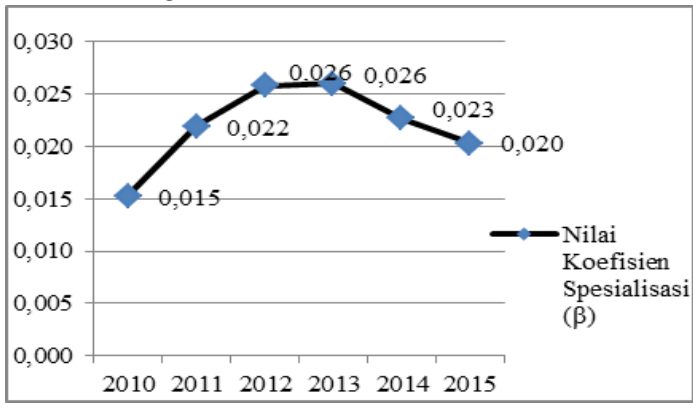

Gambar 4. Perkembangan Nilai Koefisiensi Spesialisasi ( $\beta$ ) Komoditas Kedelai Berdasarkan Indikator Produksi di Kabupaten Jember Tahun 2010-

\subsection{Daya Dukung Komoditas Kedelai di Kabupaten Jember}

5.3.1Basic Service Ratio (BSR)

Hasil analisis BSR bedasarkan indikator luas panen (ditunjukkan pada Tabel 7) menunjukkan bahwa nilai BSR yang diperoleh bernilai lebih besar dari satu $(\geq 1)$ dengan nilai rata-rata sebesar 4,547, nilai ini menunjukkan bahwa, usahatani komoditas kedelai mampu mendukung perekonomian di Kabupaten Jember. Nilai BSR berdasarkan indikator luas panen di Kabupaten Jember selama periode 2010-2015 menunjukkan hasil yang berfluktuatif dari tahun ke tahun. Nilai tersebut secara garis besar berarti bahwa Kabupaten Jember memiliki kemampuan wilayah basis kedelai dalam melayani kebutuhan pengembangan wilayah non basis. Nilai BSR tertinggi diperoleh pada Tahun 2013, yaitu sebesar 7,319 , nilai tersebut berarti bahwa 1 bagian dari luas panen komoditas kedelai digunakan untuk memenuhi kebutuhan pengembangan wilayah basis dan sisanya sebesar 6,319 digunakan untuk melayani kebutuhan guna pengembangan wilayah non basis di Kabupaten Jember.
Hasil analisis Basic Service Ratio (BSR) komoditas kedelai di Kabupaten Jember Tahun 2010-2015 berdasarkan Indikator Luas Panen adalah sebagai berikut :

\begin{tabular}{|c|c|c|c|c|}
\hline No & Tahun & $\begin{array}{c}\text { Luas } \\
\text { Panen } \\
\text { Basis }\end{array}$ & $\begin{array}{c}\text { Luas } \\
\text { Panen } \\
\text { Non Basis } \\
\end{array}$ & $\begin{array}{c}\text { Basic Service } \\
\text { Ratio (BSR) }\end{array}$ \\
\hline 1 & 2010 & 10.844 & 2.382 & 4,552 \\
\hline 2 & 2011 & 13.099 & 2.182 & 6,003 \\
\hline 3 & 2012 & 11.267 & 2.882 & 3,909 \\
\hline 4 & 2013 & 8.320 & 1.137 & 7,319 \\
\hline 5 & 2014 & 8.830 & 2.899 & 3,046 \\
\hline 6 & 2015 & 8.690 & 3.548 & 2,449 \\
\hline \multicolumn{2}{|c|}{ Rata-rata } & $10.174,952$ & $2.504,946$ & 4,547 \\
\hline
\end{tabular}

Sumber: Data Diolah, 2016

Perkembangan nilai BSR berdasarkan indikator luas panen di Kabupetan Jember periode Tahun 2010-2015 dapat digambarkan pada grafik berikut ini:

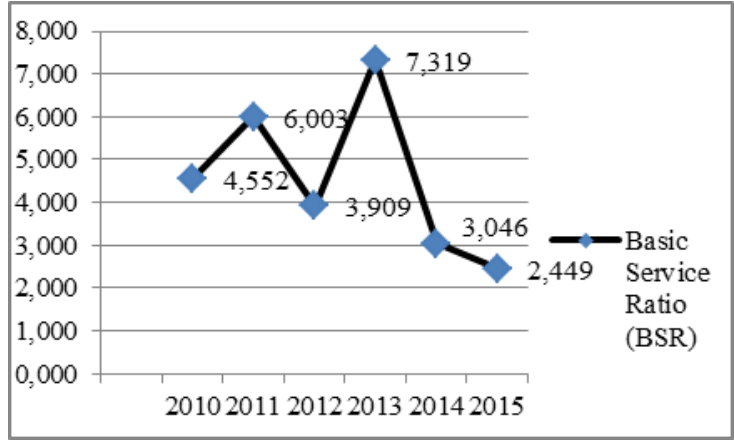

Gambar 5.Perkembangan Nilai Basic Service Ratio (BSR) Komoditas Kedelai Berdasarkan Indikator Luas Panen di Kabupaten Jember Tahun 2010-2015

Tabel 8. Nilai Basic Service Ratio (BSR) Komoditas Kedelai Berdasarkan Indikator Produksi di Kabupaten Jember Tahun 2010 - 2015

\begin{tabular}{ccccc}
\hline No & Tahun & $\begin{array}{c}\text { Produksi } \\
\text { Basis }\end{array}$ & $\begin{array}{c}\text { Produksi } \\
\text { Non Basis }\end{array}$ & $\begin{array}{c}\text { Basic Service } \\
\text { Ratio (BSR) }\end{array}$ \\
\hline 1 & 2010 & 129.120 & 58.650 & $\mathbf{2 , 2 0 2}$ \\
2 & 2011 & 215.620 & 48.540 & $\mathbf{4 , 4 4 2}$ \\
3 & 2012 & 22.695 & 5.419 & $\mathbf{4 , 1 8 8}$ \\
4 & 2013 & 188.840 & 24.640 & $\mathbf{7 , 6 6 4}$ \\
5 & 2014 & 177.540 & 61.140 & $\mathbf{2 , 9 0 4}$ \\
6 & 2015 & 173.950 & 77.830 & $\mathbf{2 , 2 3 5}$ \\
\hline \multicolumn{2}{l}{ Rata-rata } & $\mathbf{1 5 1 . 2 9 4}$ & $\mathbf{4 6 . 0 3 7}$ & $\mathbf{3 , 9 3 9}$ \\
\hline
\end{tabular}

Sumber: Data Diolah, 2016

Hasil analisis BSR komoditas kedelai berdasarkan indikator produksi di Kabupaten Jember periode Tahun 2010-2015, menunjukkan bahwa nilai rata-rata BSR komoditas kedelai berdasarkan indikator produksi di Kabupaten 
Linda Ekadewi Widyatami, Ardhitya Alam Wiguna. Analisis Perwilayahan Komoditas Kedelai

Di kabupaten jember

Jember periode Tahun 2010-2015 lebih besar dari satu (>1), dengan nilai 3,939, nilai ini menunjukkan bahwa produksi kedelai mampu mendukung pengembangan perekonomian di Kabupaten Jember. Nilai BSR komoditas kedelai berdasarkan indikator produksi di Kabupaten Jember selama periode Tahun 2010-2015 yang tertinggi berada pada tahun 2013 yaitu bernilai 7,664, nilai tersebut menunjukkan bahwa 1 bagian produksi komoditas kedelai digunakan untuk memenuhi pengembangan di wilayah basis dan sisanya sebesar 6,664 digunakan untuk melayani kebutuhan guna mengembangkan wilayah non basis.

Perkembangan nilai BSR berdasarkan indikator produksi di Kabupetan Jember periode tahun 2010-2015 dapat digambarkan pada grafik berikut ini:

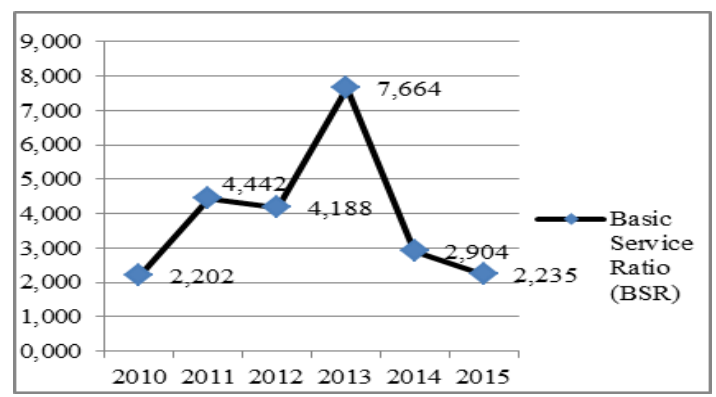

Gambar 6.Perkembangan Nilai Basic Service Ratio (BSR) Komoditas Kedelai Berdasarkan Indikator Produksi di Kabupaten Jember Tahun 2010-

\subsubsection{Regional Multiplier (RM)}

Hasil analisis Regional Multiplier (RM) Komoditas Kedelai Berdasarkan Indikator luas panen di Kabupaten Jember Tahun 2010 - 2015 ditunjukkan pada Tabel 9.

Tabel 9. Nilai Regional Multiplier (RM) Komoditas Kedelai Berdasarkan Indikator Luas Panen di Kabupaten Tahun $2010-2015$

\begin{tabular}{ccccc}
\hline \multicolumn{5}{c}{ Tahun $2010-2015$} \\
No & Tahun & $\begin{array}{c}\text { Luas } \\
\text { Panen } \\
\text { Basis }\end{array}$ & $\begin{array}{c}\text { Luas } \\
\text { Panen Non } \\
\text { Basis }\end{array}$ & $\begin{array}{c}\text { Regional } \\
\text { Multiplier } \\
\text { (RM) }\end{array}$ \\
\hline 1 & 2010 & 10.844 & 2.382 & 1,220 \\
2 & 2011 & 13.099 & 2.182 & 1,167 \\
3 & 2012 & 11.267 & 2.882 & 1,256 \\
4 & 2013 & 8.320 & 1.137 & 1,137 \\
5 & 2014 & 8.830 & 2.899 & 1,328 \\
6 & 2015 & 8.690 & 3.548 & 1,408 \\
\hline \multicolumn{7}{c}{ Rata-rata } & $\mathbf{1 0 1 7 4 , 9 5 2}$ & $\mathbf{2 5 0 4 , 9 4 6}$ & $\mathbf{1 , 2 5 3}$
\end{tabular}

Sumber: Data Diolah, 2016

Hasil analisis RM berdasarkan indikator luas panen di Kabupaten Jember menunjukkan nilai RM lebih dari saru $(\mathrm{RM}>1)$, dengan nilai rata-rata RM 1,253. Dengan demikian dapat dikatakan bahwa keberadaan pengusahaan usahatani komoditas kedelai dilihat dari indikator luas areal panennya mendukung kegiatan ekonomi tanaman pangan berupa efek pengganda yang ditimbulkan bagi kecamatan-kecamatan yang ada di Kabupaten Jember. Efek multiplier tersebut dapat berupa peningkatan pendapatan maupun penyerapan tenaga kerja baik melalui kegiatan pertanian sub sektor tanaman pangan itu sendiri maupun kegiatan sekunder industri hasil komoditas kedelai.

Perkembangan nilai RM Komoditas Kedelai Berdasarkan Indikator luas panen di Kabupaten Jember Tahun 2010 - 2015 dapat ditunjukkan pada Gambar 7 berikut ini:

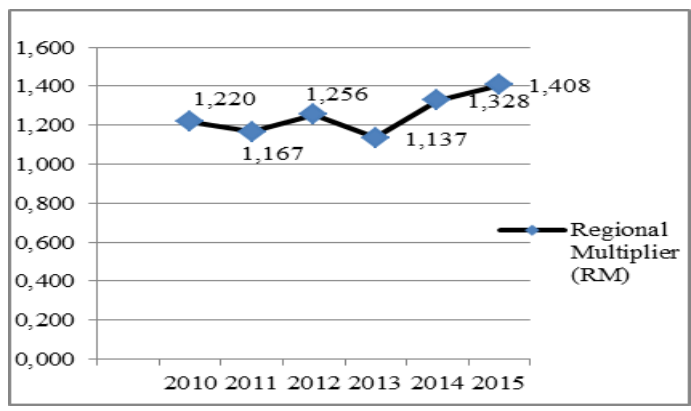

Gambar 7.Perkembangan Nilai Regional Multiplier (RM)

Komoditas Kedelai Berdasarkan Indikator Luas

Hasil analisis Regional Multiplier (RM)

Komoditas Kedelai Berdasarkan Indikator Produksi di Kabupaten Jember Tahun 2010 - 2015 ditunjukkan pada Tabel 10 berikut ini:

Tabel 10. Nilai Regional Multiplier (RM) Komoditas Kedelai Berdasarkan Indikator Produksi di Kabupaten Jember Tahun 2010 - 2015

\begin{tabular}{|c|c|c|c|c|}
\hline No & Tahun & $\begin{array}{l}\text { Produksi } \\
\text { Basis }\end{array}$ & $\begin{array}{c}\text { Produksi } \\
\text { Non } \\
\text { Basis } \\
\end{array}$ & $\begin{array}{c}\text { Regional } \\
\text { Multiplier } \\
\text { (RM) }\end{array}$ \\
\hline 1 & 2010 & 129.120 & 58.650 & 1,454 \\
\hline 2 & 2011 & 215.620 & 48.540 & 1,225 \\
\hline 3 & 2012 & 22.695 & 5.419 & 1,239 \\
\hline 4 & 2013 & 188.840 & 24.640 & 1,130 \\
\hline 5 & 2014 & 177.540 & 61.140 & 1,344 \\
\hline 6 & 2015 & 173.950 & 77.830 & 1,447 \\
\hline \multicolumn{2}{|c|}{ Rata-rata } & 151.294 & 46.037 & 1,307 \\
\hline
\end{tabular}

kedelaiberdasarkanindikator produksimenunjukkan bahwa nilai RM lebih dari satu, dengan nilai ratarata RM sebesar 1,307. Dengan demikian dapat dikatakan bahwa keberadaan pengusahaan usahatani komoditas kedelai dilihat dari indikator produksinya mendukung kegiatan ekonomi sub sektor tanaman pangan berupa efek pengganda yang ditimbulkan bagi kecamatan-kecamatan yang ada di Kabupaten Jember. Efek multiplier yang ditimbulkan tersebut dapat berupa peningkatan pendapatan maupun penyerapan tenaga kerja baik 
melalui kegiatan pertanian sub sektor tanaman pangan itu sendiri maupun kegiatan sekunder dari industri hasil komoditas kedelai. Nilai RM tertinggi terjadi pada tahun 2010 yaitu sebesar 1,454 , nilai tersebut menunjukkan bahwa, 1 bagian digunakan untuk wilayah basis dan 0,454 merupakan efek penambahan terhadap wilayah non basis.

Perkembangan nilai RM Komoditas Kedelai Berdasarkan Indikator Produksi di Kabupaten Jember Tahun 2010 - 2015, dapat ditunjukkan pada Gambar 8 berikut ini:

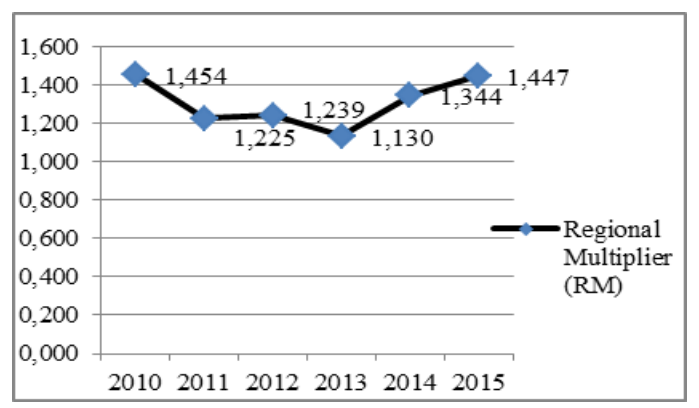

Gambar 8 Perkembangan Nilai Regional Multiplier (RM) Komoditas Kedelai Berdasarkan Indikator Produksi di Kabupaten Jember Tahun 2010-2015

\subsubsection{Analisis Penggandan Jangka Pendek (Short Multiplier)}

Analisis LQ ini dapat diperkuat dengan analisis pengganda jangka pendek (short multiplier). Efek pengganda sektor basis ini akan mengetahui sejauh mana sektor basis mempengaruhi perkembangan laju pertumbuhan ekonomi suatu wilayah basis. Dalam analisis pengganda jangka pendek, penelitian ini menggunakan asumsi bahwa faktor-faktor yang mempengaruhi penerimaan seperti investasi lokal, pendapatan dan pengeluaran masyarakat bersifat tetap.

Hasil analisis pengganda jangka pendek (short multiplier) rata-rata komoditas kedelai di Kabupaten Jember pada periode tahun 2010-2015 ditunjukkan pada Tabel 11 dibawah ini.

Tabel 11. Nilai Short Multiplier (SM) Komoditas Kedelai di Kabupaten Jember Tahun 2010-2015

\begin{tabular}{|c|c|c|c|c|}
\hline $\begin{array}{l}\mathbf{N} \\
\mathbf{o}\end{array}$ & Tahun & $\begin{array}{l}\text { Penerimaan } \\
\text { Basis }(\mathbf{R p})\end{array}$ & $\begin{array}{c}\text { Penerimaan } \\
\text { Non Basis } \\
\text { (Rp) }\end{array}$ & $\begin{array}{c}\text { Short } \\
\text { Multiplier } \\
\text { (SM) }\end{array}$ \\
\hline 1 & 2010 & 86.045 .568 .000 & 39.084 .360 .000 & 1,454 \\
\hline 2 & 2011 & 156.022 .632 .000 & 35.123 .544 .000 & 1,225 \\
\hline 3 & 2012 & 16.481 .109 .000 & 3.935 .277 .800 & 1,239 \\
\hline 4 & 2013 & 143.518 .400 .000 & 18.726 .400 .000 & 1,130 \\
\hline 5 & 2014 & 134.868 .734 .440 & 46.445 .164 .040 & 1,344 \\
\hline 6 & 2015 & 149.986 .879 .933 & 64.081 .775 .893 & 1,427 \\
\hline & $\begin{array}{c}\text { Rata- } \\
\text { rata }\end{array}$ & 114.487.220.562 & 34.566.086.956 & 1,303 \\
\hline
\end{tabular}

Hasil analisis pengganda jangka pendek komoditas kedelai di Kabupaten Jember pada periode tahun 2010-2015 bernilai lebih dari satu $(>1)$, dengan nilai rata-rata 1,303. Hal ini menunjukkan bahwa keberadaan pengusahaan komoditas kedelai mendukung kegiatan ekonomi sub sektor tanaman pangan berupa efek pengganda penerimaan jangka pendek. Mekanisme efek pengganda tersebut bekerja melalui arus perputaran nilai tambah sektor basis untuk dibelanjakan kembali pada kegiatan ekonomi sektor lain sebagai upaya pemenuhan kebutuhan suatu wilayah atas barang dan jasa yang tidak diproduksi atau terbatas di wilayah tersebut. Nilai koefisien SM diinterpretasikan sebagai tingkat penerimaan yang diperoleh wilayah atas setiap rupiah penerimaan komoditas basis kedelai.

Perkembangan nilai analisis pengganda jangka pendek (short multiplier) di Kabupaten Jember pada periode tahun 2010-2015, dapat ditunjukkan pada Gambar 9 berikut ini:

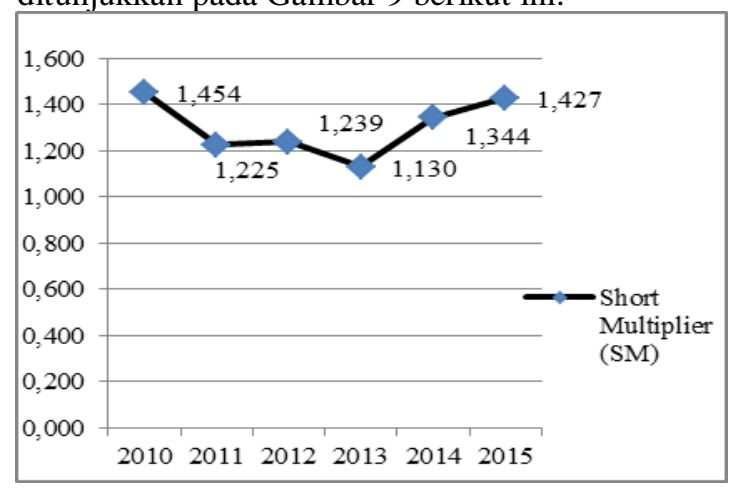

Gambar 9.Perkembangan Nilai Pengganda Jangka Pendek (Short Multiplier) Komoditas Kedelai di Kabupaten Jember Tahun 2010-2015

\section{IV.KESIMPULAN}

Kesimpulan hasil dan pembasahan dalam penelitian ini adalah sebagai berikut:

1. Wilayah Basis Komoditas Kedelai di Kabupaten Jember Tahun 2010-2015, yaitu:

a) Wilayah Basis Komoditas Kedelai berdasarkan indikator luas panen terdiri dari 10 Kecamatan yaitu: Kecamatan Bangsalsari, Umbulsari, Balung, Rambipuji, Jombang, Ajung, Kaliwates, Kencong, Jenggawah, serta Kecamatan Ambulu.

b) Wilayah Basis Komoditas Kedelai berdasarkan indikator produksi terdiri dari 9 Kecamatan yaitu: Kecamatan Bangsalsari, Umbulsari, Balung, Rambipuji, Jombang, Ajung, Kaliwates, Kencong, serta Kecamatan Jenggawah.

2. Usahatani komoditas kedelai di Kabupaten Jember tidak terkonsentrasi pada satu wilayah saja, melainkan menyebar di beberapa 
Linda Ekadewi Widyatami, Ardhitya Alam Wiguna. Analisis Perwilayahan Komoditas Kedelai

Di kabupaten jember

3. kecamatan di Kabupaten Jember. Usahatani komoditas kedelai di wilayah kecamatan basis Kebupaten Jember tidak menspesialisasikan pada usahatani komoditas kedelai.

4. Usahatani Komoditas kedelai di Kabupaten Jember berdasarkan analisis Basic Service Ratio (BSR), Regional Multiplier (RM), dan Analisis pengganda jangka pendek (short multiplier) menunjukkan bahwa dapat berperan serta dalammendukung kegiatan pertanian sektor tanaman pangan di KabupatenJember.

\section{UCAPAN TERIMAKASIH}

Tim peneliti mengucapkan terima kasih kepada Politeknik Negeri Jember dan Pusat Penelitian dan Pengabdian Kepada Masyarakat (P3M) Politeknik Negeri Jember yang telah memberikan kesempatan dan mendanai kegiatan penelitian ini melalui sumber dana BOPTN Politeknik Negeri Jember Tahun 2016.

\section{DAFTAR PUSTAKA}

[1] Badan Pusat Statistik Kabupaten Jember. 2011. Kabupaten Jember dalam Angka. Jember: Badan Pusat Statistik Kabupaten Jember.

[2] Badan Pusat Statistik Kabupaten Jember. 2011. Kabupaten Jember dalam Angka. Jember: Badan Pusat Statistik Kabupaten Jember.

[3] Badan Pusat Statistik Kabupaten Jember. 2012. Kabupaten Jember dalam Angka. Jember: Badan Pusat Statistik Kabupaten Jember.

[4] Badan Pusat Statistik Kabupaten Jember. 2013. Kabupaten Jember dalam Angka. Jember: Badan Pusat Statistik Kabupaten Jember.

[5] Badan Pusat Statistik Kabupaten Jember. 2014. Kabupaten Jember dalam Angka. Jember: Badan Pusat Statistik Kabupaten Jember.

[6] Badan Pusat Statistik Kabupaten Jember. 2015. Kabupaten Jember dalam Angka. Jember: Badan Pusat Statistik Kabupaten Jember.

[7] Badan Pusat Statistik Kabupaten Jember. 2016. Kabupaten Jember dalam Angka. Jember: Badan Pusat Statistik Kabupaten Jember.

[8] Badan Pusat Statistik Provinsi Jawa Timur. 2016. Provinsi Jawa Timur dalam Angka. Surabaya: Badan Pusat Statistik Jawa Timur.

[9] Nazir, M. 1999. Metode Penelitian. Jakarta: Ghalia.

[10] Rencana Pembangunan Jangka Menengah Nasional (RPJMN) Bidang Pangan dan Pertanian Tahun 2015-2019. Jakarta.

[11] Septiatin. 2012. Peningkatan Produksi Kedelai di Lahan Kering, Sawah, dan Pasang Surut.Bandung: Rama Widya.

[12] Soetriono. 1996. Sektor Basis Kedelai sebagai Pendukung Agroindustri di Kecamatan Ambulu Kabupaten Jember. Agrijurnal Fakultas Pertanian Universitas Jember. No. 2, Volume 3.

[13] Soetriono. 2006. Daya Saing Pertanian Dalam Tinjauan Analisis. Malang: Bayumedia.
[14] Tarigan, 2006. Ekonomi Regional Teori dan Aplikasi. Jakarta: Bumi Perkasa. Dalam Widjayanti. 2012. Perwilayahan Komoditas Sub Sektor Pertanian dalam Pengembangan Wilayah Jalur Lintas Selatan (JLS) Kabupaten Jember. Jember: Program Studi Agribisnis Program Pasca Sarjana Universitas Jember.

[15] Warpani, S. 1983. Analisis Kota dan Daerah. Bandung: ITB. Dalam Hidayat M, T. 2010. Perwilayahan dan Dinamika Perkembangan Komoditas Tembakau Di Indonesia. Jember: Program Studi Agribisnis Program Pasca Sarjana Universitas Jember.

[16] Wibowo, R dan Januar, J. 2005. Teori Perencanaan Pembangunan Wilayah. Jember: Fakultas Pertanian Universitas Jember. 